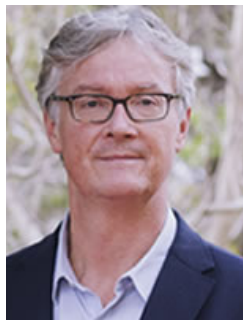

\title{
REAL DEAL OR NO DEAL? A COMPARATIVE ANALYSIS OF RAW MILK CHEESE REGULATION IN AUSTRALIA AND FRANCE
}

William van Caenegem

Bond University, Australia

\author{
Madeline E Taylor \\ Bond University, Australia
}

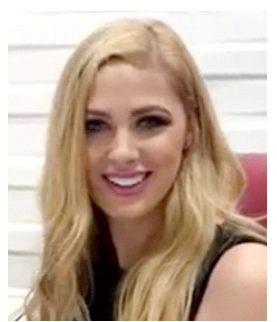

\begin{abstract}
Australia's regulatory framework has resulted in the standardisation of cheese production based on pasteurisation. Up until early 2015, regulations effectively prohibited raw milk cheese-making in Australia and thus stifled artisanal on-farm production. Although the introduction of Food Standards Australia New Zealand Standard 4.2.4 has allowed the production of certain hard, low-moisture raw milk cheeses, the new standard is rigid and does not encourage new entrants into the emerging raw milk cheese consumer market. This article compares the Australian system with the French raw milk cheese regulation and production system, and argues that its approach in encouraging and supporting small farmhouse artisanal traditional raw milk cheese is beneficial to both producer and consumer, and has not resulted in any significant health risks. The Australian approach amounts to a missed opportunity to encourage the emergence of a value-added industry with local and export potential, and is at odds with important movements in food policy, such as recognition of the value of localism and terroir.
\end{abstract}

\section{Introduction}

The use of raw milk in cheese production in Australia is controversial and has actively engaged the attention of cheese producers, dairy organisations and regulators alike. Food Standards Australia and New Zealand (FSANZ) has treated the topic with extreme care, navigating waters stirred up by the strongly advocated opinions of promotors and detractors of raw milk cheese (RMC) in Australia. Despite recent changes, the regulation of RMC production in Australia is still restrictive when compared to that of many other jurisdictions, such as France, which is the main comparator in this article and holds a strong RMC production sector. Historically, the raw milk drinking debate has greatly influenced Australian regulators. The level of risk from drinking raw milk is relatively high and well-publicised. Incidents have resulted in either a complete ban or very narrow exceptions to some permit sales in the different Australian states.

Although risks from consuming cheese made with raw milk are much lower, as we argue below, an analogous risk-adverse, rigid and prescriptive attitude to RMC regulation has taken hold in Australia. Nevertheless, the CSIRO has now recognised that:

Pasteurisation had served Australia's export-focused dairy industry well, but it is now time to change the rules. Now the industry is deregulated there is much more competition on world markets. There's now a real need for farmers to ${ }^{\circledR}$ run their own micro-dairies and sell raw drinking milk and raw cheeses. ${ }^{1}$

Further, as stated by Yoon, Lee and Choi:

Although not many countries currently permit the distribution or import of raw milk cheeses due to the prejudice against their microbiological safety, consumer interest in such products shows an increasing trend and the market continuously expands. ${ }^{2}$

(c) 2017 William van Caenegem and Madeline E Taylor. This is an Open Access article distributed under the terms of the Creative Commons Attribution 4.0 International (CC BY 4.0) License (https://creativecommons.org/licenses/by/4.0/), allowing third parties to copy and redistribute the material in any medium or format and to remix, transform, and build upon the material for any purpose, even commercially, provided the original work is properly cited and states its license.

1 Emily Stewart, 'Dairy Farmers Lead Renewed Push to Legalise Raw Milk', ABC (online), 28 March 2016 <http://www.abc.net.au/news/2016-03-28/dairy-farmers-lead-renewed-push-to-legalise-raw-milk/7274634>.

2 Yohan Yoon, Soomin Lee and Kyoung-Hee Choi, 'Microbial Benefits and Risks of Raw Milk Cheese' (2016) 63 Food Control 201, 210, DOI: 10.1016/j.foodcont.2015.11.013>. 
Unlike the present Australian RMC system, RMC makers in France are afforded derogations for small (farmhouse) production and the use of traditional methods. They are encouraged to pursue the art of RMC making and given administrative and educational support by their respective regulatory agencies and associations. The French RMC system, thus, enables small rural businesses to develop and create value in provenance-branded RMC in times of plummeting returns from standard milk supply to processors. To some extent, the French regulatory model aims to preserve a strong tradition of local and farm-based cheesemaking in the different regions - the great variety and interest of distinctive cheeses is seen as an important asset in French cultural life. However, farm based and small scale cheesemaking is also recognised as critically important in providing employment, investment and liveable returns from milk production in rural areas.

The often-stated rationale for more restrictive RMC regulation in Australia is that local consumers are less accepting of health risks than, for instance, European consumers, is not borne out by any literature that we have identified. Nor is there conclusive evidence that there are more health incidents in France or, if there are, that they can be sheeted home to greater consumption of RMC. Eight deaths, in the period 1980 to 2016, have been reported in France related to outbreaks of Listeria monocytogenes, E.coli and Salmonella in RMC. ${ }^{3}$ In relation to the positive track record of raw milk and RMC regulation in Europe, Grotenstein states: 'We know for a fact that the streets of Europe would be littered with bodies and [European] hospitals would be filled to capacity if there were a problem with unpasteurised products'. ${ }^{4}$ Almli et al. state: 'French consumers are open to safety and health innovations in traditional food', 5 and there is no evidence that consumers in France accept higher health risks from raw milk-based foods.

Nonetheless Australia adheres to a far more rigid, inflexible and prescriptive regime for RMC production. This is all the more surprising given the lively international trade in RMCs and, in particular, importation of such cheese (eg, Roquefort) from France in relatively large volumes. Australian producers are essentially put at a competitive disadvantage due to Australia's more exacting regulatory standards. Meurs, from Holy Goat Dairy in Australia, has referred to the resulting cost differential between Australian and European producers in the following terms:

\footnotetext{
We're in a global market now with cheese. We have a huge amount of imported cheese coming into Australia and we're small, specialist cheese-makers; we would like to be able to produce equal cheese, so to play on the same field as everyone else. ${ }^{6}$
}

This article discusses RMC production and regulation in Australia. It provides a comparative analysis of French RMC regulations and the French production system, and examines the case for the introduction of a more flexible and producer-sensitive RMC regulatory regime in Australia to encourage reflection of cheese terroir and the development of a viable RMC industry. We conclude that the adoption of a more flexible regime would enable local cheesemakers to make the most of the natural advantages that Australia has to offer and to produce a diverse range of cheeses with local character. Diversity and local character would also meet the emerging consumer interest in local foods that are closely associated with local terroir and particular producers, while maintaining perfectly acceptable health standards. In other words, Australian regulators can learn from the French example to strike a more productive balance between encouraging a new sector of rural economic activity while maintaining an acceptable health risk profile.

In the following section, we address on-farm and milk quality issues that are critical to the production of safe RMC.

\footnotetext{
3 Ibid 215.

4 As cited in Giuseppe Licitra, 'Worldwide Traditional Cheeses: Banned for Business?' (2010) 90 (4) Dairy Science Technology 357, DOI: $10.1051 / \mathrm{dst} / 2010016$.

5 Valérie Lengard Almli et al, 'Consumers' Acceptance of Innovations in Traditional Cheese: A Comparative Study in France and Norway’ (2011) 57(1) Appetite 110, 115, DOI:10.1016/j.appet.2011.04.009.

6 Jo Townsend, 'Raw Milk Debate', The 7:30 Report (Online), 21 April 2010 <http://www.abc.net.au/7.30/content/2010/s2879408.htm>.
} 


\title{
Quality and health standards in RMC production
}

Two factors are essential to ensuring the production of safe RMC: good dairying practice and a good understanding of social expectations of food safety and quality.

\section{Good dairying practices}

The microbial life of raw milk depends on herd health and, importantly, on the cleanliness of items with which the milk may come into contact, such as dairy equipment, workers' clothing, receptacles, milk lines and the animals' teats. Indirect sources, such as feed, litter and drinking water may also impact the microbial life of raw milk. ${ }^{7}$ Thus, the good dairying practices of the dairy farmer critically determine the microbial diversity, quality and safety of raw milk, which is further enhanced by the good cheese making practices of a skilled RMC maker. ${ }^{8}$

The RMC making industry is comparatively young and inexperienced in Australia. In other jurisdictions, such as France, traditional RMC making skills and practices have been used, transmitted and taught continuously for a long time. In these jurisdictions, wooden vats and ripening shelves, 'back slopping' whey cultures and rind smearing techniques enrich the raw milk and RMC during the cheese making process. Such techniques are unknown and/or prohibited in Australia. Such techniques activate microbial populations, improving organoleptic characteristics while at the same time countering and removing pathogenic bacteria. ${ }^{9}$ For example, the wooden ripening shelves for a variety of RMC styles contain active reservoirs of mould and yeast bacteria which act as a source of surface microflora for smear cheeses. Seiler and Busse identify more than 15 yeast species in brines of soft, hard and semi-hard cheese. Brine microbiota serves to inoculate the surface of many RMCs and, in most cases, optimise the ripening process. ${ }^{10}$ Further, RMC makers internationally use the back slopping technique, consisting of whey drained from the previous day's curd, to inoculate their raw milk for carrying out the acidification step in the RMC process. This maintains the uniqueness and specificity of the cheese over time while reducing the risk of post-production contamination.

According to Montel et al's study, consuming RMC cheese is, therefore:

\begin{abstract}
Safer than unfermented milk because fermentation (involving $\mathrm{pH}$ decrease in the core due to acid production, redox potential reduction, nutrient depletion and antagonistic metabolite production) ... and a ripening temperature often below $15^{\circ} \mathrm{C}$, creates environmental conditions that are more or less hostile to pathogens depending on manufacturing and ripening process. ${ }^{11}$
\end{abstract}

As indicated above, the farm environment is identified by the literature as potentially contributing to the pathogenic transfer of bacterial contamination to raw milk if a dairy farm does not maintain herd health and adhere to good dairying practices. The quality of raw milk can easily be individually tested and, of course, depends on the practices and abilities of individual farmers. However, in terms of Australian standards more generally, a study by McAuley et al examined the occurrence of nine foodborne pathogens in raw milk and the environments of seven dairy farms (three bovine, three caprine, and one ovine farm) in summer and autumn, in Victoria, Australia. The study found:

High standards of pathogen safety across the 7 farms, with a low incidence of pathogens detected in raw milk samples ... Monitoring feed contamination levels may help control the spread of bacterial species such as $\mathrm{Cl}$. perfringens and $\mathrm{B}$. cereus through the farm environment, which is a natural reservoir for these organisms. ${ }^{12}$

\footnotetext{
7 Marie-Claude Julien et al, 'Sources of Clostridia in Raw Milk on Farms' (2008) 82(12) AEM 6348, DOI: 10.1128/AEM.00913-08.

8 Marie-Christine Montel et al, 'Traditional Cheeses: Rich and Diverse Microbiota with Associated Benefits' (2014) 177 International Journal of Food Microbiology 136, DOI: 10.1016/j.ijfoodmicro.2014.02.019.

9 L Settanni et al, 'Persistence of Wild Streptococcus Thermophilus Strains on Wooden Vat and During the Manufacture of a Traditional Caciocavallo Type Cheese' (2012) 155 International Journal of Food Microbiology 73, DOI: 10.1016/j.ijfoodmicro.2012.01.022.

${ }^{10} \mathrm{H}$ Seiler and M Busse, 'The Yeasts of Cheese Brines' (1990) 11 International Journal of Food Microbiology. 289,DOI: 10.1016/0168-1605(90)90022-W.

${ }^{11}$ Montel et al, above n 8, 138 .

${ }^{12}$ Catherine M Mcauley et al, 'Prevalence and Characterization of Foodborne Pathogens from Australian Dairy Farm Environments’ (2014) 97 Journal of Dairy Science 7402, 7403, DOI: 10.3168/jds.2014-8735.
} 
McAuley et al took 120 samples from points common to dairy farms, including pasture, soil, feed, water sources, animal faeces, raw milk and milk filters. The incidence of STEC, L. monocytogenes, Campylobacter and $Y$. enterocolitica was low across all farms, and Salmonella was detected on only a single farm. McAuley et al's study provides evidence of the inherently safe and clean dairy environments in Victoria, one of Australia's key dairying and cheesemaking states, leading to the conclusion that the production of RMC starts from a general Australian baseline of high quality and safety based on high raw milk standards. ${ }^{13}$ An important factor in this high standard of Australian raw milk, compared to Europe, for instance, is that, overwhelmingly, Australian herds are pasture-fed. For example, according to Griffiths, barn bedding is a significant cause of udder and Campylobacter faecal contamination. ${ }^{14}$

Two conclusions result from the above analysis that are relevant when considering how to implement to a balanced regulatory approach. First, that properly adapted farming and milking practices can produce very clean raw milk with a bacterial profile that enables safe manufacture of RMC, and that Australian dairy farmers start from a high baseline position in this regard. Second, that certain traditional artisanal RMC making practices further enhance the safety of the resulting product. In this context, it is important to recognise that access to traditional artisanal practices is central to RMC making not only to ensure specificity and diversity but also to improve safety and health outcomes.

In the next section, we examine the relationship between varying conceptions of quality and the safety of RMC. A more nuanced approach that does not simply equate quality with safety results in more balanced regulations based on the understanding that organoleptic quality and safety go hand-in-hand.

\section{Interpretations of safety and conceptions of quality}

Naturally, food safety is the principal concern of the regulatory systems in both France and Australia. Nonetheless the two countries have adopted strikingly different approaches to regulation, based on varying conceptions of safety and acceptable risk, and how it can be best assured by regulatory intervention in production processes.

At the heart of this difference lies varied understandings of the concept of quality amongst consumers and regulators in relation to different food segments. The impact of these perceptions of quality and safety, and their interaction on regulatory design is critically important.

In particular, in relation to artisan food products provenance, tradition and the involvement of skilled craftsmanship are central to consumer evaluation of quality. These factors coalesce around the concept of terroir. While this notion is relatively new and more contested in Australia, it is well-established and broadly accepted in local food production in France and other European countries. RMC, in contrast to industrialised pasteurised cheese, is seen as having organoleptic qualities strongly influenced by the specific terroir of its place of origin. Terroir is a concept that refers to the natural vegetation, grasses, microclimate, animal breeds and landscape unique to a more or less defined area and the production methods that have developed around them. Paxson defines terroir as a:

Notion of place [which] refers not only to the material conditions of a locale - soil, topography, microclimate - but also to the collective, cultural know-how behind agricultural products that helps to constitute place as a locus of shared tradition and affective belonging. ${ }^{15}$

Terroir can only impart a particular quality to a cheese through the medium of raw (non-pasteurised) and, therefore, bacteriologically live, milk. At the very least, using pasteurised milk severely limits the potential for cheese to reflect the local environment. Uniqueness, reflectiveness and a distinct sensory profile are thus essential aspects of perceived quality for RMC.

A study by van Rijswijk and Frewer found that two-thirds of consumer respondents perceived there to be a strong relationship between quality and safety of food because consumers believed '[q]uality and safety are

\footnotetext{
13 Ibid, 7405.

${ }^{14}$ M Griffiths, Improving the Safety and Quality of Milk: Milk Production and Processing (Woodhead Publishing, 2010$) 31$.

${ }^{15}$ Heather Paxson, The Life of Cheese (University of California Press, 2012) 188.
} 
two very close connected concepts. A product of a high quality is automatically safe'. ${ }^{16}$ According to Ilbery and Kneafsy, consumers' culturally embedded expectation of 'traditional' and 'artisan' foods mean they trust such quality foods as safe. ${ }^{17}$

In contrast, Shaw argues that conflating quality with safety has made food choices and negotiating food risks problematic and a continuous challenge in the presence of imperfect scientific knowledge and understanding. ${ }^{18}$ The concept of 'risky' food versus 'safe' food becomes highly contested and evolving amongst consumers who are sceptical about industrialised food systems in which science seems to fail to prevent often highly publicised - food safety crises. A 'quality turn' has resulted from this perception, whereby consumers place their confidence in artisan agricultural producers who habitually and historically construct and negotiate risks in producing food in their daily lives. ${ }^{19}$ Natural, traditional and local foods, therefore, trigger the 'quality turn' and a growing proportion of consumers have turned to such foods to satisfy their concerns about food safety, quality, environmental sustainability and taste.

Specific to RMC is the food safety risk of pathogenic growth in cheeses. However, D'Amico argues that food safety authorities' identification of the supposedly acute risks of RMC pathogenic outbreaks is 'unpersuasive' as Listeria, Salmonella and E. coli growth are all possible in both pasteurised cheese and RMC. ${ }^{20}$ This is because of the possibility of pathogenic outbreaks in a cheese production facility where bacteria may grow and spread on factory working surfaces, machinery and farming equipment. ${ }^{21}$ The risk of contamination is no different between pasteurised cheese and RMC. Further, a substantial fraction of the risk results from relatively common health problems found in cows, and can be mitigated by measures that should, in any case, be applied to all herds regardless of whether milk is to be pasteurised for cheesemaking; for example, tuberculosis or brucellosis, and, more relevantly today in Australia, mastitis in herds.

Sage examined the exclusion of a broader concept of quality within food safety risk assessment and uncertainty about purely scientific risk evaluations for RMC. He studied an Irish case concerning the presence of bovine tuberculosis in a milking herd which resulted in the prohibition of the defendant making RMC. The court found in favour of the RMC maker. O'Donnabhain $\mathrm{J}$ said:

\begin{abstract}
I am convinced that the Department are moving with a conviction to which all science must bend. There is a considerable gap in their science in what happens with the milk and the cheese making process. The Department's evidence is defective in relation to this cheese making process and is based entirely on speculation and the need to get the science to match the conviction that the cheese is contaminated. I am convinced ... that there is no risk to the human population in eating the cheese. ${ }^{22}$
\end{abstract}

\title{
Quality, terroir, science and regulatory outcomes
}

A considerable problem revealed by the Irish case analysed by Sage is that when scientific risk is not conclusive, food safety regulators tend to take the view that there must be a risk to consumers, regardless of the claimed quality of the RMC. The onus of proof, therefore, is on the RMC maker to prove its product as 'safe'. This places a heavy burden on cheese makers to prove scientifically - in the presence of great scientific uncertainty - that there is no risk involved with RMC production and distribution. However, artisan

${ }^{16}$ Wendy van Rijswijk and Lynn J Frewer, 'Consumer Needs and Requirements for Food and Ingredient Traceability Information' (2012) 36(3) International Journal of Consumer Studies 282, 288, DOI: 10.1111/j.14706431.2011.01001.x).

${ }^{17}$ Brian Ilbery and Moya Knefsey, 'Registering Regional Speciality Food and Drink Products in the United Kingdom: The Case of PDOs and PGls' (2000) 32(3) Area 317 <http: / /www.jstor.org/stable/20004084>

${ }^{18}$ Ian Shaw, Is it Safe to Eat? Enjoy Eating and Minimize Food Risks (Springer, 2005).

19 Jonathan Murdoch and Mara Miele, 'A New Aesthetic of Food?: Relational Reflexivity in the 'Alternative' Food Movement' in Mark Harvey, Andrew McMeekin and Alan Warde (eds) Qualities of Food (Manchester University Press, 2004) 156, <http://www.jstor.org/stablej.ctt155j52v.14>.

${ }^{20}$ Dennis D’Armico and C W Donnelly, 'Microbiological Quality of Raw Milk Used for Small-Scale Artisan Cheese Production in Vermont: Effect of Farm Characteristics and Practices’ (2010) 93(1) Journal of Dairy Science 134, DOI: $10.3168 /$ jds.2009-2426.

${ }^{21}$ Claire E Price et al, 'From Meadows to Milk to Mucosa: Adaptation of Streptococcus and Lactococcus species to their Nutritional Environments' (2012) Microbiology Reviews 949, DOI: 10.1111/j.1574-6976.2011.00323.x.

${ }^{22}$ Colin Sage, "'Bending Science to Match their Convictions": Hygienist Conceptions of Food Safety as a Challenge to Alternative Food Enterprises in Ireland' in Alternative Food Geographies: Representation and Practice, D Maye, L Holloway and M Kneafsey (eds) (Elsevier, 2007) 203, 205. 
RMC making processes (such as bio-chemical transformation, maturation or affinage) that enhance quality and uniqueness have experientially (rather than strictly scientifically) proven the elimination of pathogens within RMC.

Nonetheless RMC in Australia has been subjected to a particularly stringent regulatory framework by FSANZ, which is evidentially not inclusive of an extensive definition of 'quality'. As Sage points out in relation to the selling of raw meat, the approach to RMC also:

Reveals a contradiction in a food safety policy that expects consumers to cook the meat thoroughly before eating, yet they are not permitted to buy a product in which the milk from animals has been bio-chemically transformed rendering it safe for consumption. ${ }^{23}$

Food safety is embedded within the concept of food quality, which suggests that a broader and more complex understanding of artisanal food quality and skill must inform regulation of RMC in Australia than is actually the case. Employing a more modulated conception of quality allows for a nuanced definition of safety as the basis of food governance, beyond science and inclusive of the concepts of terroir, sustainability and artisanal skill as indirect parameters contributing to reliably safe food.

\section{Raw milk cheese: Standard regulation vs local variations in terroir}

As explained above, the term terroir represents the environmental, social and gastronomic values reflected in the flavour and appearance of local artisanal food products: the goût du terroir. As stated by Kessler:

Every raw-milk cheese is an artefact of the land; it carries the imprint of the earth from which it came. A cheese - even a fresh chèvre - is never just a thing to put in your mouth. It's a living piece of geography. A sense of place. ${ }^{24}$

Given that to be safe and of high gustatory quality, RMC making requires a supply of fresh milk of consistently high quality, milk production and cheesemaking must be united in one specific place, or at least be located in very close proximity. This reduces the delay between milking and the start of cheesemaking, avoiding quality deterioration in the milk. Also, proximity militates against the mixing of milk from different sources. The effect of different breeding and feeding techniques, the composition and health of the herd, and temporal variations in the milk quality can, then, not be observed or controlled. Mixing or sourcing from distant dairies also results in variations of the milk quality, so that the terroir quality can no longer be guaranteed.

Therefore, terroir, with its emphasis on localism, is an integral part of RMC, as argued above. For example, Comte is a distinct artisan RMC relying on a terroir tradition and has a unique sensory profile rooted in the micro-climate and topography of the French Alps. This particular quality results from a long process of experimentation and observation by local cheese makers; from learning-by-doing rather than a formal research project. Trubek states that Comté cheese terroir is 'as timeless as the earth itself' ${ }^{25}$ Further, Marcellino et al suggest: 'If one faithfully follows a traditional technique based on a natural microbial succession, one is able to create a new product characteristic of one's own land'. ${ }^{26}$ With the aim of preserving, improving and reflecting the qualities of terroir; in some areas, back slopping techniques have been used by artisan RMC makers for centuries, with no adverse health effects. Back slopping is 'where the whey obtained at the end of cheesemaking is incubated at $20^{\circ} \mathrm{C}$ for $16-18$ hours to be reused as starter culture in the following cheese batch'. ${ }^{27}$ Rai and Bai highlight the importance of back-slopping which 'allows [the] constant evolvement of natural starters'. ${ }^{28}$ The indigenous microbiota generate the distinctive

\footnotetext{
${ }^{23}$ Ibid.

${ }^{24}$ Brad Kessler, Goat Song: A Seasonal Life: A Short History of Herding, and the Art of Making Cheese (Scribner, 2010$) 10$.

${ }^{25}$ Amy Trubek, 'Tasting Problems and Errors of Perception' in Carolyn Korsmeyer, The Taste Culture Reader Experiencing Food and Drink (Berg Publishers, 2010) 272.

${ }^{26} \mathrm{~N}$ Marcellino et al, 'Diversity of Geotrichum Candidum Strains Isolated from Traditional Cheesemaking Fabrications in France' (2001) 67 (10) Applied and Environmental Microbiology 4752, DOI: 10.1128/AEM.67.10.4752-4759.2001.

${ }^{27}$ Rai V Ravishankar and A Bai Jamuna, Beneficial Microbes in Fermented and Functional Foods (CRC Press, 2015) 17.

${ }^{28}$ Ibid.
} 
flavour of RMC due to a high and very specific profile of Lactococcus spp., Lactobacillus spp., Leuconostoc spp., and Enterococcus spp., creating each RMC's unique terroir. ${ }^{29}$

Important in the RMC regulatory debate is the fact that the universally high instance of natural microbiota within raw milk used in RMC making reduces or eliminates pathogenic growth due to the development of an inherent microbiological balance. 'Good bacteria' combat 'bad bacteria', resulting in an 'extremely low or zero percentage of raw milk cheese (being) contaminated by major pathogens including Listeria monocytogenes' ${ }^{30}$ Other studies have shown that, in fact, the microbiological profile of raw milk varies from farm to farm. ${ }^{31}$

Additionally, a recent study by Bassi, Puglisi and Cocconcelli points to the significant advantage in the use of or reliance upon selected and natural starter cultures as compared to 'adventitious microbiota' (standard starter cultures) in terms of acidification, sensory traits, as well as in the control of undesired microorganisms. ${ }^{32}$ Thus, raw milk has both important safety advantages as well as enhancing flavour and other gustatory qualities of cheese.

Another important factor in the RMC the regulatory debate, is the fact that the variety of indigenous microbiota unique to each terroir makes it very difficult to regulate all RMC production and RMC types 'scientifically' in a 'one size fits all' regime. What is required is a regulatory scheme which has flexibilities that accept local variation in the microbiological profile of raw milk:

Since the composition of the raw milk microbiota appears to vary according to the region and livestock species from which it is produced, there is no consistency in the antagonistic effect of microbiota of raw milk against pathogenic bacteria. ${ }^{33}$

In other words, raw milk microbiota in one area might have a more profound effect on countering the growth of pathogenic bacteria in one region or terroir than in another. Not only is there geographical variation, there is also significant temporal change to take into account. Indigenous cultures, unlike commercially bought starter cultures, are continuously evolving according to seasonal and environmental variations. Feutry et al's microbiological study of RMC concluded:

When Cheddar cheese was produced using cow or buffalo milk and using respectively commercial and indigenous cultures of Lactococcus lactis subsp. lactis and Lc. lactis subsp. cremoris, sensory characteristics were improved in cheese made by native bacteria. ${ }^{34}$

Therefore, focusing on tested, sustainable and traditional local RMC making practices will not only enhance the ability of cheesemakers to impart interesting properties and characteristics of flavour that reflect locality and are not homogenous and immutable, but also increase their ability to produce safe cheese. The regulatory regime should, thus, be flexible enough to recognise that a variety of local techniques should be encouraged to persist. If that is allowed to happen, the multifarious and unique topographies and microclimates within Australia will be allowed to deliver on the promise of a wide range of safe, diverse and unique RMCs.

In the next section we highlight the impact of the GI regulation model on RMC making. Cheeses with a registered geographical indication are subject to specific production standards that ensure consistent quality but also enhance safety. Australia does not have a similar regulatory scheme for cheese.

\footnotetext{
${ }^{29}$ Erick Casalta, et al,' 'Diversity and Dynamics of the Microbial Community During the Manufacture of Calenzana, an Artisanal Corsican Cheese' (2009) 133(3) International Journal of Food Microbiology 243 DOI: 10.1016/j.ijfoodmicro.2009.05.022.

${ }^{30}$ C L Little et al, 'Microbiological Quality of Retail Cheeses made from Raw, Thermized or Pasteurized Milk in the UK.' (2007) 25 Food Microbiology 304, DOI: 10.1016/j.fm.2007.10.007.

${ }^{31}$ Karine Lavoie et al, 'Characterization of the Fungal Microflora in Raw Milk and Specialty Cheeses of the Province of Quebec’ (2012) 92(5) Dairy Science Technology 455, DOI: 10.1007/s13594-011-0051-4.

32 Daniella Bassi, Edoardo Puglisi and Pier Cocconcelli, 'Understanding the Bacterial Communities of Hard Cheese with Blowing Defect’ (2015) 52 Food Microbiology 106, DOI:10.1016/j.fm.2015.07.004.

${ }^{33}$ Yoon, above n 2, 210.

${ }^{34}$ Torre Feutry, Garcia Arana and Caslta Desmasures, 'Lactococcus Lactis Strains from Raw Ewe's Milk Samples from the PDO Ossau-Iraty Cheese Area: Levels, Genotypic and Technological Diversity' (2012) 92 (6) Dairy Science and Technology 655, DOI: 10.1007/s13594-012-0084-3.
} 


\section{The impact of the PDO and PGI system in France}

In France, unlike in Australia at present, terroir is embedded within the appellation d'origine protégée (protected designation of origin (PDO)) and appellation d'origine contrôlé (protected designation of origin $(P G I))$ geographic origin labelling $(\mathrm{Gl})$ regulatory system. Pursuant to the Gl system, only products produced in a provenance region may be manufactured and sold under a registered $\mathrm{GI}$ name. ${ }^{35}$ Seventy-eight per cent of the RMC produced in France has both PDO and PGI certification. ${ }^{36}$ Specifying the production method and region of origin, AOC-based French RMC represents 10 per cent of French cheese production and 17 per cent of the value of the 173473 tonnes produced in France in $2009 .{ }^{37} \mathrm{Gl}$ laws in France regulate the entire manufacturing process of a RMC to ensure its safety and quality. For example, GI laws may regulate the breed of animal, milking conditions, where the animal must graze and set traditional cheese-making steps needed to be afforded GI protection. ${ }^{38} \mathrm{Gl}$ regulations encourage collectivisation of farming, promotion of provenance and traditional artisanal practices. Although RMC production levels are high, the level of farm consolidation remains low in producing RMC. Therefore, small-scale farmhouse cheese makers remain as integral to the French RMC production structure.

Local RMC making associations exist in France to structure collaboration between cheese makers and provide key technical support for PDO cheeses such as Comté, Reblochon, Saint-Nectaire and Roquefort. Comté is the biggest PDO cheese with a production of 54257 tons in 2014; Reblochon is the second largest with 15140 tons in 2014. ${ }^{39}$

Each cheese PDO has an organisme de defense et de gestion (defence and management organisation (ODG)) to which all producers contribute a levy to the administering PDO peak body, which provides quality and safety oversight requirements for each PDO-protected cheese. It applies to both raw milk producers and RMC makers. The milk producer receives advice and ongoing support from the relevant PDO association, which also undertakes quality audits and additional tests (eg, for Reblochon, three tests per month for staphylococci and E. coli) conducted by government-certified testing laboratories. Quality audits are also undertaken in the cheese-making facility with additional bacteriological checks, over and above those that are mandated by the general laws and regulations. Manufacture of PDO RMC is also commonly subject to a requirement of maximum distance between milk and cheese producers (eg, $25 \mathrm{~km}$ for Comté) and the requirement that the cheese production process be initiated within 24 hours (by renetting). ${ }^{40}$ Additionally, certain feeds for raw milk herds, such as silage, may be prohibited.

Importantly, given the high proportion of RMC production being PDO-governed in France, practices required by PDO specifications set very high standards in terms of milk quality, hygiene and use of proven practices. This has considerable additional safety benefits. For instance, many PDOs require extended ageing (eg, for Comté, a minimum of 120 days but sometimes over one year). However, although production criteria and close monitoring of production processes are crucial to a PDO cheese, the quality of the milk supplied is seen as the crucial guarantee of cheese quality and safety. This pursuit of high milk quality in PDOs is in perfect accord with a broader emphasis in France upon improving the quality of milk more generally, resulting in enhanced farmer incomes.

The Australian RMC regulations are yet to encompass the concept of terroir and its intrinsic safety and gustatory values within a suitably flexible regulatory framework. The GI regulatory system does not, as yet,

${ }^{35}$ William van Caenegem, Peter Drahos and Jennifer Cleary, Australia's Regions and Agriculture: Can Geographical Indications Help? (2015) Rural Industries Research and Development Corporation

$<$ https://rirdc.infoservices.com.au/downloads/15-060>.

${ }^{36}$ Carol Terracina Hartman et al, The Benefits and Risks to the Producer and Consumer of Cheese made from Raw (Unpasteurized) Milk (2011) Cheese Society <http://www.cheesesociety.org/wp-content/uploads/2011/02/ACS-2011Montreal-Raw-Milk-Cheese-Track-Summary.pdf>.

${ }^{37}$ Ibid.

${ }^{38}$ Paxson, above n 15, 188.

${ }^{39}$ Maison Du Lait, France: The Perfect Example of a Cheese Making Country! (2016) CNIEL < http://www. maison-dulait.com/en/milk-products/cheeses>.

${ }^{40}$ Bryan Newman, Comte AOP (AOC), the Premiere Cheese of France (2013) Behind the French Menu <http://behind-thefrench-menu.blogspot.com.au/2013/01/comte-aop-aoc-premiere-cheese-of-france.html>. 
exist in Australia, although some have called for its introduction. ${ }^{41}$ Nonetheless the concept of terroir has the potential to enhance the unique standing of RMC compared to pasteurised milk cheese. Because terroir means small scale local production using typical techniques, it has the potential to revitalise rural regions in Australia and contribute to a potential new era of food governance encompassing regulation and protection of artisanal practices and agrarian communities. As stated by Paxon: 'raw-milk cheese might be forwarded as a biotechnology (derived from the scientific use of living organisms or parts of organisms) for regionalism or, in more contemporary argot, for localism, the expression of a people's connection to a piece of land'. ${ }^{42}$

In the next section, we set out the regulatory schemes in Australia and France in more detail, highlighting some of the principle differences.

\title{
Raw milk cheese production and regulation
}

In Australia, FSANZ standard 4.2.4 regulates the production of RMC. In France, RMC is governed by the EU Standards for Dairy Farms and for Milk Sold for Human Consumption. The following section will compare the Australian and French regulatory standards for RMC, and contrast the policy support for small, local and farmhouse artisan cheesemakers of the two jurisdictions.

\section{Australia: FSANZ Standard 4.2.4}

Prior to 2015, only cooked curd RMC was permitted for production in Australia by FSANZ. Only four Australian cheesemakers had received licenses to produce such cooked curd RMC. Division 4 of Standard 4.2.4, clause 16 required either pasteurisation for milk or dairy products used to make cheese or cheese products or:

\begin{abstract}
(b) by being held at a temperature of no less than $62^{\circ} \mathrm{C}$ for a period of no less than 15 seconds, and the cheese or cheese product stored at a temperature of no less than $2^{\circ} \mathrm{C}$ for a period of 90 days from the date of processing; or (c) such that - (i) the curd is heated to a temperature of no less than $48^{\circ} \mathrm{C}$; and (ii) the cheese or cheese product has a moisture content of less than $36 \%$, after being stored at a temperature of no less than $10^{\circ} \mathrm{C}$ for a period of no less than 6 months from the date of processing; or (d) in accordance with clause 1 of Standard 4.2.4A. ${ }^{43}$
\end{abstract}

A two year review (Proposal P1022) of the FSANZ Food Standards Code Standard 4.2.4, which governs production and sale of RMC in Australia, culminated in the release of a FSANZ Approval Report (AR) on P1022 on 16 December 2014. The earliest iteration of P1022 relating to changes to the standard for RMC making underwent two rounds of submissions regarding their effectiveness. In particular, the European Union and private Australian cheese makers highlighted the restrictiveness of Proposal 1022.

Proposal P1007 established a risk-based category approach to assess permissions for raw milk products. P1007 identified three categories for assessment and defined them in terms of the effect that processing factors and product properties of the final product have on pathogen survival and growth:

- Category 1 products are those products for which the properties and/or processing factors eliminate pathogens that may have been present in the raw milk;

- Category 2 products are those products for which the properties and/or processing factors may allow survival of pathogens that may have been present in the raw milk but do not support the growth of these pathogens; and

\footnotetext{
${ }^{41}$ See William van Caenegem, Peter Drahos and Jen Cleary, 'Provenance of Australian food products: Is There a Place for Geographical Indications?’, RIRDC (2015), <https://rirdc.infoservices.com.au/items/15-060>.

42 Paxson, above n 15, 26.

${ }^{43}$ FSANZ, Supporting Document 1: Guide to the Requirements for Raw Milk Cheese in Standard 4.2.4 - Primary Production and Processing Standard for Dairy Products (at approval) - Proposal P1022 Primary Production and Processing Requirements for Raw Milk Cheese (2014) FSANZ <http://www.foodstandards.gov.au/code/proposals/Documents/P1022-Rawmilk-prods-AppR-SD1.pdf>.
} 
- Category 3 products are those products for which the intrinsic properties and/or processing factors are likely to allow the survival of pathogens that may have been present in the raw milk and may support the growth of these pathogens. ${ }^{44}$

Proposal P1007 concluded that, for category 1 and 2 products, there are combinations of specific production and processing controls that can provide a product with an acceptable level of public health risk. For category 3 products, the level of risk cannot be reduced sufficiently and such products are held to present a high level of public health and safety risk. ${ }^{45}$ RMCs within Category 3 , because they may 'allow the survival of pathogens that may have been present in the raw milk and may support the growth of those pathogens' will be refused permission.

Clause 34 of P1007 contains a three-tiered framework checklist as a framework for regulators and cheesemakers to identify whether a RMC is permissible for sale:

(1) Prior to the commencement of its processing, milk for raw milk cheese must be monitored to ensure its suitability;

(2) The level of pathogenic microorganisms in a raw milk cheese must not exceed the level of pathogenic microorganisms in the milk from which the product was made as at the commencement of the processing of that milk; and

(3) A raw milk cheese must not support the growth of pathogenic microorganisms. ${ }^{46}$

Therefore, Clause 34 requires monitoring and testing of RMC at input and at outcome levels. SD1 specifies:

$$
\begin{aligned}
& \text { Initially it would be expected that a representative sample of each raw milk tank/silo is tested } \\
& \text { prior to manufacture. Over time, sufficient data may be obtained such that a reduced frequency } \\
& \text { is adequate, depending on the relationship between the dairy primary production business and } \\
& \text { the processing business and the type of cheese being produced. Recommended tests and ac- } \\
& \text { ceptable limits for total plate count and generic } E \text {. coli are provided below. Monitoring for } \\
& \text { pathogens, such as } L \text {. monocytogenes and Salmonella should also be considered. }{ }^{47}
\end{aligned}
$$

Additionally, Standard 1.6.1 imposes mandatory requirements for lot or consignment testing before sale. This results in a heavy burden of sampling, testing and analysis imposed on any maker of RMC, irrespective of production volumes and with no modification as to risk levels and profile of a particular RMC maker.

The 'no net increase' of pathogens requirement is, in effect, addressed by control measures, CCPs or hurdles expressed in terms of tolerances such as $\mathrm{pH}$ and water levels documented in the food safety program (FSP). The raw milk and RMC business need to validate that these control point tolerances are correctly identified and logged and that compliance with them will ensure no net growth. SD1 states 'the processing factors that impact on microbial growth and inactivation and include these as CCPs. The parameters (critical limits) that must be met and how these are verified (eg, log sheets/analytical results) should also be specified' ${ }^{48}$ This equates to a very onerous requirement of record keeping that is universally imposed on any RMC-making business, irrespective of its size in Australia.

Bacterial and possible pathogenic qualities of raw milk to be pasteurised are of little consequence due to the low survival rate of pathogens and bacteria during high heat pasteurisation. However, raw, unpasteurised milk used for cheesemaking must be of high quality with low plate counts, bacterial counts and little likelihood of supporting pathogenic growth. This necessarily requires control over herd management and milking practices of a herd supplying raw milk for cheesemaking. The FSANZ Standard 4.2.4 is very prescriptive concerning many aspects of herd management, such as feed regimes, animal identification, storage and animal housing. The further requirement within Standard 4.2.4 to utilise raw milk for cheesemaking within 24 hours is important to ensure the quality of the raw milk does not deteriorate before cheesemak-

${ }^{44}$ FSANZ, Proposal P1022 - Primary Production and Processing Requirements for Raw Milk Products (2014)

FSANZ<http://www. foodstandards.gov.au/code/proposals/pages/proposalp1022primary5627.aspx>.

${ }^{45}$ FSANZ, Supporting Document 1, above $\mathrm{n} 43$.

${ }^{46}$ FSANZ, Proposal P1022, above $n 44$.

${ }^{47}$ FSANZ, Supporting Document 1 Guide, above n 43.

${ }^{48}$ Ibid. 
ing starts. This helps to ensure that there is no net pathogenic growth in RMC making because of the low incidence or absence of pathogenic microbial in the milk. Farmhouse cheesemakers and other cheesemakers with strong relationships and proximity to their raw milk supplier are thus essential. This is consistent with D'Amico, Groves and Donnelly's findings that farmhouse cheeses made from raw milk of cow, sheep and goat display a low incidence of bacterial pathogens, such as S. aureus, Salmonella, and E. coli 0157:H7, suggesting that RMC is microbiologically safe. ${ }^{49}$

The Australian RMC standards, therefore, are very prescriptive concerning aspects of milk production, cheese making processes (with proscription of many traditional techniques) and record-keeping. In addition, there is little flexibility based on differential risk assessment of individual businesses, producers' size or track record. The imposed testing regime is multifarious and expensive for small makers. These aspects of the Australian regulations are further highlighted in our comparison with the French approach below.

\section{French RMC regulations and practice}

France has a long-standing tradition of cheesemaking, both at the industrial level with some large dairy processors and exporters, such as Lactalis, Sodiaal (a cooperative) and Danone, and a rich artisanal RMC sector with many SMEs, small scale farmhouse cheesemakers and PDO cheeses. Dairy is a very significant industry in France, despite individual French dairy farms remaining comparatively small. The average size of a French dairy farm is 52 cows on 32 hectares of pasture land with each dairy herd having at least three random milk analysis tests monthly. ${ }^{50}$ By comparison, the average size of an Australian dairy farm is far greater with 254 cows on 398 hectares of pasture land. ${ }^{51}$

There are a number of critical distinctions between the regulatory environment for RMC production in Australia and France. The French regulations are governed by overarching European legislation: the $E U$ standards for dairy farms and for milk sold for human consumption..$^{52}$ Regulatory flexibilities and derogations mitigate the impact of the full panoply of standard regulatory requirements on small and farmhouse producers (ie, cheese makers who produce raw milk and RMC on-farm). The French audit and inspection regime is flexibly adapted to producer size, assessed risk level and production levels.

The other crucial difference in the French RMC regulations is that, where cheese Gls exist, much higher standards in terms of milk quality and production safety apply in practice, in contrast to the requirements of general cheese regulations. Gl protected RMCs are an integral part of the artisanal cheese making landscape. More generally, a clear policy exists towards improving milk quality across the board in the French dairy industry which aids with safe RMC production. High quality milk meeting somatic cell, total germs, drug residues, protein, fat and freezing point requirements attracts higher prices..$^{53}$ As stated by CNIEL 'This system of milk payment, based on a reference price plus a bonus and malus system, encourages farmers to produce milk of the highest quality'. ${ }^{54}$

\section{The artisanal link in the French cheese production chain}

The cheese making environment in Europe is different to Australia as there is a long and less interrupted tradition of local artisanal cheese-making at a small scale and using traditional methods and styles that are often unique to a locality. Although in France there has been some increase in industrialised manufacture, the country continues to identify cheesemaking with variety, quality and artisanal production. As stated by

49 D J D'Amico, E Groves and C W Donnelly, 'Low Incidence of Foodborne Pathogens of Concern in Raw Milk Utilized for Farmstead Cheese Production' (2008) 71(8) Journal of Food Protection 1580, 1589, DOI:10.4315/0362-028X.JFP-10-533.

${ }^{50}$ Maison Du Lait, 50 Facts About the French Dairy Industry (2016) CNIEL <http://www. maison-du-lait.com/en/keyfigures/50-facts-about-french-dairy-industry>.

${ }^{51}$ Dairy Australia, Dairy in South West Victoria (2016) West Vic Dairy <http://www.westvicdairy.com.au/AboutWestVicDairy/DairyinSouthWestVictoria.aspx>.

52 Including EU Regulation No 605/2010 for the Importation of Raw Milk Dairy Products into the EU which Apply to France as Elsewhere in Europe.

${ }^{53}$ Frederic Bertassi, Safety of Milk and Dairy Products in France (2015), Animaweb <http://www.animaweb.org/uploads/Reamed-formation/DGAL_SafetyMilk\&DairyProducts_31-3-15.pdf>.

${ }^{54}$ Masion Du Lait, The Dairy Economy in Figures (2013) CNIEL, 2 <http://fr.calameo.com/read/002230051aea002d0612e>. 
Richez-Lerouge: '[t]here will always be cheese but it won't be the same if we don't hold on to the old, rural and artisanal methods passed down the generations'. ${ }^{55}$

Australia has imitated and adopted European cheese styles and the basic production methodology that applies to them, resulting in a limited range of mostly processed and low-moisture content aged cheeses, such as cheddar. By contrast, French cheesemakers have recognised 'raw milk is essential (to artisanal cheesemaking). Pasteurised milk is dead and preserving microbes is the key to everything: flavour, texture and smell'.56

The artisanal and PDO sector in France is based on the use of traditional local methods that result in the distinctiveness of the cheese, together with the raw milk sourced from a unique environment representing its terroir. The regulations in France are sensitive to these traditional and historically proven practices, they recognise that, in terms of hygiene and food safety, applied techniques have acted as a real life laboratory. Regulatory acceptance of traditional practices, rather than a purely scientific approach to food safety, accords with the EU's adaptive, reflexive, more result-oriented regulatory approach. This different approach translates into some key requirements that make the Australian RMC regulations more onerous. Some of these were addressed by the French Dairy Interbranch Organisation (CNIEL) in their FSANZ submission:

- The frequency of analysis of raw milk is once a week in Standard 4.2.4. In France, a milk sample is taken every day at the time of milk collection but the analysis is made randomly 2 or 3 times a month;

- The acceptable limit for $E$. coli is $10 \mathrm{cfu} / \mathrm{ml}$ in Standard 4.2.4. E. coli, is not regulated in France/Europe for raw milk at farm level and companies are free to determine the limit regarding the performance objective. The risk is linked to enterotoxin production by $S$. aureus, when concentrations are above $105 \mathrm{cfu} / \mathrm{g}$; and

- According to Standard 4.2.4, milk for raw milk products must be cooled to a temperature of $6^{\circ} \mathrm{C}$ or below within 2 hours of it being milked, unless processing is to commence within 2 hours of it being milked. In France, EC regulation 853/2004 requires cooling of milk at the temperature of $8^{\circ} \mathrm{C}$ or below within the 2 hours following milking (however when milking is not performed every day, the milk must then be cooled at $6^{\circ} \mathrm{C}$ or below). ${ }^{57}$

More generally, the Australian RMC regulations are very prescriptive when compared to the French regime. Australian regulations have a far greater proportion of rules that instruct RMC (but not pasteurised milk cheese) producers to follow specified practices, prohibit others and impose particular forms of record keeping. By contrast, the standards for pasteurised milk cheese are results-based, not prescribing or outlawing certain techniques or practices. In France, the core RMC standards are also holistic and resultoriented. ${ }^{58}$ The specific and detailed measures that will ensure that those standards are met are for the producer to determine, reflecting the 'new' approach introduced with the European food hygiene regulations in 1992/93: 'protéger le consommateur en fixant des objectifs à atteindre par les producteurs ... tout en laissant ces producteurs libres de définir les moyens d'y parvenir' ('protecting the consumer by setting goals the producers must achieve ... while leaving the latter to determine the measures required to do so'). This amounts to an 'obligation de résultats et responsabilité active des producteurs' ('a result-based obligation and responsibility on producers to be pro-active'). ${ }^{59}$ In other words, the regulatory approach is more consistent between pasteurised milk and RMC production in France, whereas, in Australia, we adopt a part-prescriptive approach to RMC and a results-based approach to pasteurised milk cheese.

\footnotetext{
${ }^{55}$ As cited in David Chazan, 'French Traditionalists Praise Warning from Prince Charles that Artisanal Cheese Could Disappear' The Telegraph (online) 6 December 2015 <http: / /www.telegraph.co.uk/news/worldnews/europe/france/12036040/French-traditionalists-praise-warning-fromPrince-Charles-that-artisanal-cheese-could-disappear.html>.

${ }^{56}$ Ibid.

${ }^{57}$ CNIEL, Answer from the French Dairy Sector to the Call for Submissions FSANZPproposal 1022 (2014) FSANZ, 3-6 <http://www.foodstandards.gov.au/code/proposals/pages/proposalp1022primary5627.aspx>.

${ }^{58}$ EUR-LEX, Directive 2004/41/CE DU Parlement Europeen et du Conseil DU 21 Avril 2004 (2004) <http: / / eurlex.europa.eu/legal-content/FR/TXT/?uri=celex\%3A32004L0041>.

${ }^{59}$ Maurielle Cahen, Obligations de moyens et obligations de resultat (2014) <http://www. muriellecahen.com/publications/obligation.asp>.
} 
However, importantly French RMC producers are not left to their own devices as to how to translate the result-oriented standards into practical and detailed measures. Producers are assisted by detailed guidance from professional representative bodies, which is given official status or 'validated' ('validé') by relevant organisations such as the 'Institut de l'Elevage'. The most crucial of these is the 'Guide de Bonnes Pratiques Hygieniques Validé ${ }^{\prime 60}$. Although voluntary, the Guide is drafted by skilled technicians and then validated by professionals in five milk-producing regions under the guidance of a national steering committee consisting of administrators, professionals and certain organisations.

\section{Farmhouse, local and small scale RMC production}

The French RMC regulatory flexibilities are twofold: regulatory imposts and audit requirements for small supplier enterprises; and less onerous requirements for local cheese production distributed retailer to retailer within a limited geographical radius. ${ }^{61}$ In particular, small operators (as defined in France as producing less than 2000000 litres of milk per annum) have a more lenient system of hazard control - 'in accordance with EU Hygiene Package regulations, the application of Good Hygiene Practices, the HACCP plan and operational tools based on the quantitative microbiological risk assessment (QMRA)' ${ }^{62}$ This approach does not impose particular control points, and does not require the continuous monitoring and record keeping concerning production process steps normally required by HACCP. It is framed by a 'Note de Service' (Administrative Memorandum), ${ }^{63}$ which states that the production facilities benefitting from the more relaxed approach will usually be farmhouse based (ateliers de production fermiere). The Administrative Memorandum also provides for variation on the standard regulatory requirements found in the EU regulations. For instance, in relation to the separation of different cheese production areas, permission is granted to use a single area for a number of cheese making operational steps and attendant requirements for farm-house cheesemakers.

In France any food processing businesses, including any RMC cheese maker, normally requires safety certification granted by local authorities, the Directions Départementales de la Protection des Populations (Departmental Directorates for Public Protection (DDPP)), before it is entitled to place any product on the market. ${ }^{64}$ The safety certification requires the submission of a full and comprehensive application or dossier. However, an exception applies whereby there is a relaxation of the regime for retail to retail supply of food products, including RMC, when the producer complies with proximity and volume requirements. ${ }^{65}$ In some cases, simply filing a declaration with the relevant local authority is sufficient (articles 12-15). The annual declaration need only list the products that will be supplied, the purchasers of the product, and the amounts produced and supplied.

In order for a RMC maker to qualify for this exception, the distance between buyer and seller cannot be more than $80 \mathrm{~km}$, although this may be extended to $200 \mathrm{~km}$ where particular geographical conditions justify it, for instance in particularly mountainous regions. There is also a maximum volume limit of $250 \mathrm{~kg}$ per week if this represents less than 30 per cent of the total production of the business, or $100 \mathrm{~kg}$ per week if the product so supplied constitutes more than 30 per cent of total production. ${ }^{66}$ Thus, cheese makers who supply locally, for instance to retailers or market stall holders, are subject to less onerous administrative

\footnotetext{
${ }^{60}$ A European equivalent is in the process of elaboration and at present at the stage of consideration of official recognition: Institut de l'Elevage, Guide Européen de Bonnes Pratiques en Transformation Laitière Fermière et Artisanale (2015) Idele.fr <http://idele.fr/domaines-techniques/produire-et-transformer-du-lait/produitsfermiers/publication/idelesolr/recommends/guide-europeen-de-bonnes-pratiques-en-transformation-laitiere-fermereet-artisanale.html>.

${ }^{61}$ At the European level, derogations and flexibilities are permitted by art 13 of reg 852/2004 of 29 April 2004 on the hygiene of foodstuffs; and art 10 of reg 853/2004 of 29 April 2004 laying down specific hygiene rules for the hygiene of foodstuffs.

${ }^{62}$ CNIEL, above n $57,5$.

${ }^{63}$ Agriculture France, DGAL/SDSSA/N2011-8239 of 7 November 2011 <http://agriculture.gouv.fr/ministere/note-deservice-dgalsdssan2011-8239-du-07112011>

${ }^{64}$ Note de Service DGAL, Dossier Type d'Agrément pour les Ateliers Laitiers Fermiers se Livrant à la Préparation de Lait ou de Produits Laitiers (7 April 2014) Agriculture France

<http://agriculture.gouv.fr/sites/minagri/files/documents/pdf/Fermier_laitier_Dossier_type_agrement_fermier_3_cl e8886de.pdf>.

${ }^{65}$ Decree of 8 June 2006, JORF 08/08/2006; and Decree of 27 April 2007 amending the Decree of 8 June 2006 Relatif à l'Agrément, and the Note de Service (NS) of 19/02/08).

${ }^{66}$ Ibid, annex 3.
} 
requirements. ${ }^{67}$ The safety of the product is reliable because there are no intermediaries, transport distances are short and the product is destined for quick sale to consumers.

The DGAL (Ministry of Agriculture) in France has developed a risk-based audit frequency system for food businesses ${ }^{68}$ which was last evaluated in $2015 .{ }^{69}$ Four factors are taken into account to calculate risk and thus audit frequency: a risk evaluation applicable to the particular activity concerned (eg, a higher risk will be ascribed to RMC than to pasteurised milk cheese); the volume of production; the risk sensitivity profile of the relevant consumer category (eg, children and babies have a higher risk profile); and the general outcome of the previous audit. These factors are combined to determine an audit frequency ranging from two audits (inspections) per year to one every three years (eg, for producers of raw milk for drinking). The effect of the application of a risk analysis is generally beneficial to small and farmhouse producers because their volume of production is small and the product is not directed at a particularly vulnerable group (as for instance baby milk formula would be). The risk analysis based audit regime means smaller establishments will be less frequently audited.

\section{Traditional methods}

By virtue of Decree 7 of November 2012, ${ }^{70}$ certain traditional methods are expressly permitted in France regarding materials, equipment, packaging, processing, treatments and ageing. Commonly accepted materials used in cheese production are wood, brass, copper, natural stone, tin, straw or vegetable mats and leaves. Further, traditional structures or places within which cheese may be made or stored, for example for affinage, are permitted. A principal object of the Decree is to enable the continued use of methods established by tradition in cheesemaking facilities that either come under PDO local specifications (or 'cahier de charge', which often call for the use of such methods). However, it allows such processes and materials to be employed in any farmhouse style operation so that it can continue to rely upon traditional artisanal methods. These methods are usually labour intensive, relying on artisanal hand-tools and equipment.

An instructive example is the permitted use of wood and wooden surfaces during the manufacture of RMC. ${ }^{71}$ This traditional material, although strictly prohibited in Australia, has, in fact, been shown to enhance safety as well as the organoleptic characteristics of cheese. ${ }^{72}$ Microbial biofilms found on wooden surfaces traditionally used for cheese ripening, are used by European cheese makers as a natural pathogen protection. According to Montel et al, Salmonella, L. monocytogenes and E. coli 0157: H7 are generally absent from RMC ripening on vat wooden surfaces and $S$. aureus is rarely detected on the surface of wooden vats in which milk is curdled. ${ }^{73}$ On wooden shelves used for cheese ripening, neither Listeria nor Salmonella has been detected and $S$. aureus and $E$. coli were below $10 \mathrm{cfu} / \mathrm{cm}^{2}$ in recent experiments analysing pathogens

${ }^{67}$ Cheese makers who fall within the parameters are not subject to the requirements of reg (EC) No 853/2004 of 29 April 2004, which lays down specific hygiene rules for on the hygiene of foodstuffs.

${ }^{68}$ Note d'information, Stratégie des Contrôles DDPP pour 2011-2015 (2015) FNEC <http://www.fnec.fr/IMG/pdf/note_strategie_controles_DGAL_VDEF.pdf>.

${ }^{69} \mathrm{EU}$, Audit de la Méthodologie de Programmation des Contrôles Officiels en Fonction d'une Hiérarchisation des Risques dans le Domaine de la Sécurité Sanitaire des Aliments (2015) CGAAER <http://www.ladocumentationfrancaise.fr/var/storage/rapports-publics/164000056.pdf>.

${ }^{70}$ VMS, Arrêté du 7 Novembre 2012 Relatif aux Règles Sanitaires Applicables aux Produits Laitiers Présentant des Caractéristiques Traditionnelles (NOR: AGRG1237700A) (7 November 2012) Domaine De La Securite Sanitaire Des Aliments <http://agriculture.gouv.fr/sites/minagri/files/vms_lait_et_produits_laitiers_1.0.pdf>. See also art 7 of European Regulation 2074/2005, which, in art 7, allows certain derogations by member states in relation to traditional foods.

${ }^{71}$ Decree of 7 November 2012, Minster of Agriculture, Agrofood and Forestry, 'Relatif aux Regles Sanitaires Applicables aux Produits Laitiers Presentant des Caracteristiques Traditionelles' (in relation to hygiene requirements for dairy products with traditional characteristics'). The European regulations leave it up to member states to define traditional methods.

${ }^{72}$ For a detailed analysis of the use of the 'gerle', a traditional open wooden cask, see Laurence Berrard and MarieChristine Montel, 'La Gerle: Le Vivant Invisible Entre Traditions et Norms d'Hygiene', in Bernadette Lizet and Jacqueline Milliet (eds), Animal Certifié Conforme: Déchiffrer nos Relations avec le Vivant (Dunod, 2012).

${ }^{73}$ Montel et al, above n 8, 136. 
in a study of RMC by Mariani et al. ${ }^{74}$ according to the microbiological study by Guillier et al, the dense colonisation of wooden equipment by yeasts and bacteria inhibits pathogens by restricting nutrient supply. ${ }^{75}$

This example reinforces the fact that traditional RMC practices essentially act as a natural food safety standard for cheese makers through centuries of applied experimentation. The knowledge concerning traditional methods in France is transportable and can be readily adapted to Australian local conditions.

\section{Implications and recommendations}

Currently, Australia's cheese production is considerable; exports alone amount to a total of 624416 tons of dairy products per year, of which 38960 tons is cheddar cheese exports and 86239 tons of other cheese exports. ${ }^{76}$ Within this context, RMC production represents just a fraction of Australian cheese production as there are only four existing RMC makers in Australia. ${ }^{77}$ Australia has a strong and valid basis to develop a local, small business and on-farm based RMC sector, given its high milk standards and largely pasture-fed herds. However, the highly prescriptive and inflexible regulatory requirements are adverse to the realisation of this opportunity, and its consequential benefits in terms of rural development. Standard 4.2.4 amounts to one of the most obvious differentiators from the more practical and holistic approach of the regulatory regime in France, which has a contrastingly flourishing RMC sector.

Comparing RMC in France and Australia at the regulatory and structural level, there are a number of significant differences. Firstly, for RMC production there are no separate mandatory requirements prescribed in France as there are in Australia. The same regulatory standards apply to all cheese, but the additional risks inherent in RMC production are managed at the enforcement level, with an adapted regime of inspections and controls which is determined by a general risk analysis of each cheese production facility. The selfcontrol system thus applies generally with no special rules for RMC, but with increased vigilance by enforcement authorities.

Secondly, in terms of regulatory requirements included in the Hazard Analysis and Critical Control Points (HACCP) and a food safety control plan, there are more legislated derogations and exceptions applicable to the small businesses typically involved in RMC production, determined by way of milk turnover, and by production levels and supply distances. This is a relevant comparator, because, in Australia, an RMC producers will also likely remain small and regionally based. Significantly, there is also an adaptable inspection and control regime where the frequency of tests and audits is determined on the basis of a risk analysis and a number of known factors are taken into account.

Due, in part, to the significance of the PDO/PGI GI system, other artisanal RMC cheese-making techniques are recognised and promoted in France. The GI system is critically important in France, and generally imposes higher standards and thus also guarantees the safety of cheese, even if, inherently, the cheese is high risk. The GI system gives considerable support to its members in terms of establishing safety practices and maintaining them. But even outside PDO/PGI regions, support levels for cheese makers and for RMC makers are much higher and more organised in France compared to Australia. The emergence of RMC cheeses unique to the Australian terroirs and the creation of a possible protected Gl's for Australian RMC cheese with high standards of quality in the broadest sense have not been aided by the continuing restrictiveness in terms of production methods in FSANZ Standard 4.2.4.

Our analysis of the literature concerning RMC quality and safety, and the comparison with a very successful and safe RMC producing jurisdiction, suggest some broader recommendations that go beyond regulatory amendments to produce more flexible rules. They address not only production standards but also RMC

\footnotetext{
${ }^{74} \mathrm{C}$ Mariani et al, 'Biofilm Ecology of Wooden Shelves used in Ripening the French Raw Milk Smear Cheese Reblochon de Savoie’ (2007) 90(4) Journal of Dairy Science 1653, DOI: 10.3168/jds.2006-190.

${ }^{75} \mathrm{~L}$ Guillier et al, 'Modelling the Competitive Growth Between Listeria Monocytogenes and Biofilm Microflora of Smear cheese wooden shelves' (2008) 128(1) International Journal of Food Microbiology 71, DOI:10.1016/j.ijfoodmicro.2008.06.028.

${ }^{76}$ Brooke Tonkin, Cheese Manufacturing in Australia (2016) lbis World

<http://clients1.ibisworld.com.au.ezproxy.bond.edu.au/reports/au/industry/default.aspx?entid=1856>.

77 Three in South Australia and one in Tasmania: Udder Delights (South Australia), Hindmarsh Valley Dairy (South Australia) and Woodside Cheese Wrights (South Australia). Bruny Island Cheese (Tasmania).
} 
marketing with a view to stimulating consumer interest and increasing consumer recognition of Australian RMC in the highly profitable cheese and processed dairy market.

\section{Conclusion}

We propose that a number of key points be considered when amending the current Australian RMC regulations. Firstly, the RMC regulations should be amended to a standard equivalent to the French rules which represent a 'best practice' benchmark. Optimal implementation is also critical, so training and education for dairy and food safety regulators and auditors in artisanal RMC production techniques is an essential concomitant of the new regulatory model. However, in the final analysis, safety depends on the actors in the system. Because we argue that high quality enhances (rather than equates with) safety, training and education of Australian RMC makers to learn and safely deploy traditional artisan RMC practices, is critically important. Upskilling RMC makers will enable the level of confidence that typically supports French cheese production and regulation to develop in Australia.

Finally, informative labelling for consumers of Australian RMC products would enhance both safety (enabling informed consumer choices) and the marketing image of RMC based on the varied terroirs found in Australia. This approach to developing and promoting Australian RMC would be further advanced by the adoption of an Australian RMC GI regime. Importantly, RMC cannot be dissociated from its microbiological characteristics, artisanal skill and reflection of the local environment. Australian RMC makers should be afforded the opportunity to operate in a flexible and properly adapted regulatory environment in which they may create innovative, safe and quality RMC. The French regulatory model establishes that greater flexibility and adaptation to the particular conditions of small scale and local artisanal food production can generate a RMC production sector that meets consumer demand both in terms of safety, and in terms of variety, interest and quality.

\section{Bibliography}

Agriculture France, DGAL/SDSSA/N2011-8239 of 7 November 2011 (7 November 2011) <http://agriculture.gouv.fr/ministere/note-de-service-dgalsdssan2011-8239-du-07112011>

Almli, Valérie Lengard et al, 'Consumers’ Acceptance of Innovations in Traditional Cheese: A Comparative Study in France and Norway’ (2011) 57(1) Appetite 110, 115:

https://doi.org/10.1016/j.appet.2011.04.009

Bassi, Daniella, Edoardo Puglisi and Pier Cocconcelli, 'Understanding the Bacterial Communities of Hard Cheese with Blowing Defect’ (2015) 52 Food Microbiology 106: https://doi.org/10.1016/j.fm.2015.07.004

Berrard, Laurence and Marie-Christine Montel, 'La Gerle: Le Vivant Invisible Entre Traditions et Norms d'Hygiene', in Bernadette Lizet and Jacqueline Milliet (eds), Animal Certifié Conforme: Déchiffrer nos Relations avec le Vivant (Dunod, 2012)

Bertassi, Frederic, Safety of Milk and Dairy Products in France (2015), Animaweb <http://www.animaweb.org/uploads/Reamed-formation/DGAL_SafetyMilk\&DairyProducts_31-3-15.pdf>

Cahen, Maurielle, Obligations de Moyens et Obligations de Resultat (2014) <http: / www.muriellecahen.com/publications/obligation.asp>

Chazan, David, 'French Traditionalists Praise Warning from Prince Charles that Artisanal Cheese could Disappear' The Telegraph (online) 6 December 2015

<http: / / www.telegraph.co.uk/news/worldnews/europe/france/12036040/French-traditionalists-praisewarning-from-Prince-Charles-that-artisanal-cheese-could-disappear.html>

CNIEL, Answer from the French Dairy Sector to the Call for Submissions FSANZ Proposal 1022 (2014) FSANZ, 3-6 <http://www.foodstandards.gov.au/code/proposals/pages/proposalp1022primary5627.aspx>

D'Amico, D J, E Groves and C W Donnelly, 'Low Incidence of Foodborne Pathogens of Concern in Raw Milk Utilized for Farmstead Cheese Production' (2008) 71(8) Journal of Food Protection 1580, 1589: https://doi.org/10.4315/0362-028X.JFP-10-533

D’Armico, Dennis and Donnelly, C W, ‘Microbiological Quality of Raw Milk Used for Small-Scale Artisan Cheese Production in Vermont: Effect of Farm Characteristics and Practices' (2010) 93(1) Journal of Dairy Science 134: https://doi.org/10.3168/jds.2009-2426 
Dairy Australia, Dairy in South West Victoria (2016) West Vic Dairy <http:/ / www.westvicdairy.com.au/AboutWestVicDairy/DairyinSouthWestVictoria.aspx>

Erick Casalta, et al, 'Diversity and Dynamics of the Microbial Community During the Manufacture of Calenzana, an Artisanal Corsican Cheese' (2009) 133(3) International Journal of Food Microbiology 243: https://doi.org/10.1016/j.ijfoodmicro.2009.05.022

EU, Audit de la méthodologie de programmation des contrôles officiels en fonction d'une hiérarchisation des risques dans le domaine de la sécurité sanitaire des aliments (2015) CGAAER

<http://www.ladocumentationfrancaise.fr/var/storage/rapports-publics/164000056.pdf>.

EUR-LEX, Directive 2004/41/CE DU Parlement Europeen et du Conseil DU 21 Avril 2004 (2004) <http: //eurlex.europa.eu/legal-content/FR/TXT/?uri=celex\%3A32004L0041>

Feutry, Torre, Garcia Arana and Caslta Desmasures, 'Lactococcus Lactis Strains from Raw Ewe's Milk Samples from the PDO Ossau-Iraty Cheese Area: Levels, Genotypic and Technological Diversity’ (2012) 92 (6) Dairy Science and Technology 655, DOI: 10.1007/s13594-012-0084-3: https://doi.org/10.1007/s13594-012-0084$\underline{3}$

FSANZ, Proposal P1022 - Primary Production and Processing Requirements for Raw Milk Products (2014) FSANZ<http://www.foodstandards.gov.au/code/proposals/pages/proposalp1022primary5627.aspx>

FSANZ, Supporting document 1: Guide to the Requirements for Raw Milk Cheese in Standard 4.2.4 - Primary Production and Processing Standard for Dairy Products (at Approval): Proposal P1022 Primary Production and Processing Requirements for Raw Milk Cheese (2014) FSANZ

<http://www.foodstandards.gov.au/code/proposals/Documents/P1022-Raw-milk-prods-AppR-SD1.pdf>

Griffiths, M, Improving the Safety and Quality of Milk: Milk Production and Processing (Woodhead Publishing, 2010) 31: https://doi.org/10.1533/9781845699437 and https://doi.org/10.1533/9781845699420

Guillier, L et al, 'Modelling the Competitive Growth Between Listeria Monocytogenes and Biofilm Microflora of Smear Cheese Wooden Shelves’ (2008) 128(1) International Journal of Food Microbiology 71: https://doi.org/10.1016/j.ijfoodmicro.2008.06.028

Ilbery, Brian and Knefsey, Moya, 'Registering Regional Speciality Food and Drink Products in the United Kingdom: The case of PDOs and PGls' (2000) 32(3) Area 317 <http://www.jstor.org/stable/20004084>

Institut de l'Elevage, Guide Européen de Bonnes Pratiques en Transformation Laitière Fermière et Artisanale (2015) Idele.fr <http://idele.fr/domaines-techniques/produire-et-transformer-dulait/produits-fermiers/publication/idelesolr/recommends/guide-europeen-de-bonnes-pratiques-entransformation-laitiere-fermere-et-artisanale.html>

Julien, Marie-Claude et al, 'Sources of Clostridia in Raw Milk on Farms' (2008) 82(12) AEM 6348: https://doi.org/10.1128/AEM.00913-08

Kessler, Brad, Goat Aong: A Seasonal Life: A Short History of Herding, and the Art of Making Cheese (Scribner, 2010) 10

L Settanni et al, 'Persistence of Wild Streptococcus Thermophilus Strains on Wooden Vat and During the Manufacture of a Traditional Caciocavallo Type Cheese’ (2012) 155 International Journal of Food Microbiology 73: https://doi.org/10.1016/j.ijfoodmicro.2012.01.022

Lavoie, Karine, et al, 'Characterization of the Fungal Microflora in Raw Milk and Specialty Cheeses of the Province of Quebec' (2012) 92(5) Dairy Science Technology 455: https://doi.org/10.1007/s13594-0110051-4

Licitra, Giuseppe, 'Worldwide Traditional Cheeses: Banned for Business?’ (2010) 90 (4) Dairy Science Technology 357: https://doi.org/10.1051/dst/2010016

Little, C L, et al, 'Microbiological Quality of Retail Cheeses made from Raw, Thermized or Pasteurized Milk in the UK.' (2007) 25 Food Microbiology 304: https://doi.org/10.1016/j.fm.2007.10.007

Maison Du Lait, 50 Facts About the French Dairy Industry (2016) CNIEL < http://www.maison-dulait.com/en/key-figures/50-facts-about-french-dairy-industry>

Maison Du Lait, France: The Perfect Example of a Cheese Making Country! (2016) CNIEL <http://www.maison-du-lait.com/en/milk-products/cheeses>

Marcellino, N, et al, 'Diversity of Geotrichum Candidum Strains Isolated from Traditional Cheesemaking Fabrications in France' (2001) 67 (10) Applied and Environmental Microbiology 4752: https://doi.org/10.1128/AEM.67.10.4752-4759.2001

Mariani, C et al, 'Biofilm Ecology of wooden Shelves used in Ripening the French Raw Milk Smear Cheese Reblochon de Savoie' (2007) 90(4) Journal of Dairy Science 1653: https://doi.org/10.3168/jds.2006-190 
Masion Du Lait, The Dairy Economy in Figures (2013) CNIEL, 2

<http://fr.calameo.com/read/002230051aea002d0612e>

Mcauley, Catherine M, et al, 'Prevalence and Characterization of Foodborne Pathogens from Australian Dairy Farm Environments' (2014) 97 Journal of Dairy Science 7402, 7403: http://dx.doi.org/ 10.3168/jds.2014$\underline{8735}$

Montel, Marie-Christine et al, 'Traditional Cheeses: Rich and Diverse Microbiota with Associated Benefits' (2014) 177 International Journal of Food Microbiology 136:

https://doi.org/10.1016/j.ijfoodmicro.2014.02.019

Murdoch, Jonathan and Miele, Mara, 'A New Aesthetic of Food?: Relational Reflexivity in the 'Alternative' Food Movement' in Harvey Mark, Andrew McMeekin and Alan Warde (eds) Qualities of Food (Manchester University Press, 2004) 156 <http://www.jstor.org/stablej.ctt155j52v.14>.

Newman, Bryan, Comte AOP (AOC), The Premiere Cheese of France (2013) Behind the French Menu <http://behind-the-french-menu.blogspot.com.au/2013/01/comte-aop-aoc-premiere-cheese-offrance.html>

Note d'Information, Stratégie des contrôles DDPP pour 2011-2015 (2015) FNEC <http://www.fnec.fr/IMG/pdf/note_strategie_controles_DGAL_vDEF.pdf>.

Note de Service DGAL, Dossier Type d'Agrément pour les Ateliers Laitiers Fermiers se Livrant à la Préparation de Lait ou de Produits Laitiers $(7$ April 2014) Agriculture France <http://agriculture.gouv.fr/sites/minagri/files/documents/pdf/Fermier_laitier_Dossier_type_agrement_f ermier_3_cle8886de.pdf>

Paxson, Heather, The Life of Cheese (University of California Press, 2012) 188

Price, Claire E, et al, 'From Meadows to Milk to Mucosa: Adaptation of Streptococcus and Lactococcus Species to their Nutritional Environments' (2012) Microbiology Reviews 949: https://doi.org/10.1111/j.1574-6976.2011.00323.x

Ravishankar, Rai V, and A Bai Jamuna, Beneficial Microbes in Fermented and Functional Foods (CRC Press, 2015) 17

Sage, Colin, "'Bending Science to Match their Convictions': Hygienist Conceptions of Food Safety as a Challenge to Alternative Food Enterprises in Ireland' ((Critical Public Geographies Working Paper) UCC, 2077 <http://www.ucc.ie/en/media/academic/geography/documents/publicgeographiesworkingpapers/sage07 03.pdf>

Seiler, H and Busse, M, 'The Yeasts of Cheese Brines' (1990) 11 International Journal of Food Microbiology. 289: https: //doi.org/10.1016/0168-1605(90)90022-W

Shaw, Ian, Is it Safe to Eat? Enjoy Eating and Minimize Food Risks (Springer, 2005)

Steward, Emily, 'Dairy Farmers Lead Renewed Push to Legalise Raw Milk', ABC (online), 28 March 2016 <http://www.abc.net.au/news/2016-03-28/dairy-farmers-lead-renewed-push-to-legalise-rawmilk/7274634>

Terracina Hartman, Carol et al, The Benefits and Risks to the Producer and Consumer of Cheese Made from Taw (Unpasteurized) Milk 2011) Cheese Society <http://www.cheesesociety.org/wpcontent/uploads/2011/02/ACS-2011-Montreal-Raw-Milk-Cheese-Track-Summary.pdf>

Tonkin, Brooke, Cheese Manufacturing in Australia (2016) Ibis World <http://clients1.ibisworld.com.au.ezproxy.bond.edu.au/reports/au/industry/default.aspx?entid=1856>

Townsend, Jo, 'Raw Milk Debate', The 7:30 Report (Online), 21 April 2010 <http://www.abc.net.au/7.30/content/2010/s2879408.htm>

Trubek, Amy, 'Tasting Problems and Errors of Perception' in Carolyn Korsmeyer, The Taste Culture Reader Experiencing Food and Drink (Berg Publishers, 2010) 272

van Caenegem, William, Peter Drahos and Jen Cleary, 'Provenance of Australian Food Products: Is There a Place for Geographical Indications?', RIRDC (2015), <https://rirdc.infoservices.com.au/items/15-060>

van Caenegem, William, Peter Drahos and Jennifer Cleary, Australia's Regions and Agriculture: Can Geographical Indications Help? (2015) Rural Industries Research and Development Corporation <https://rirdc.infoservices.com.au/downloads/15-060>

van Rijswijk, Wendy and Frewer, Lynn J, 'Consumer Needs and Requirements for Food and Ingredient Traceability Information’ (2012) 36(3) International Journal of Consumer Studies 282, 288:

https://doi.org/10.1111/j.1470-6431.2011.01001.x 
VMS, Arrêté du 7 Novembre 2012 Relatif aux Règles Sanitaires Applicables aux Produits Laitiers Présentant des Caractéristiques Traditionnelles (NOR: AGRG1237700A) (7 November 2012) Domaine De La Securite Sanitaire Des Aliments

<http://agriculture.gouv.fr/sites/minagri/files/vms_lait_et_produits_laitiers_1.0.pdf>

Yoon, Yohan, Lee, Soomin and Choi, Kyoung-Hee, 'Microbial Benefits and Risks of Raw Milk Cheese' (2016) 63 Food Control 201, 210: https://doi.org/10.1016/j.foodcont.2015.11.013

Decree of 8 June 2006, JORF 08/08/2006 (Fr)

Decree of 27 April 2007 Amending the Decree of 8 June 2006 Relatif à L'agrément (Fr)

Decree of 7 November 2012, Minster of Agriculture, Agrofood and Forestry 'Relatif aux Regles Sanitaires Applicables aux Produits Laitiers Presentant des Caracteristiques Traditionelles' (in relation to hygiene requirements for dairy products with traditional characteristics')

European Regulation $n^{\circ}$ 2074/2005

Note de Service (NS) of 19/02/08) (Fr)

Regulation (EC) 853/2004 of 29 April 2004

Regulation (EC) 852/2004 of 29 April 2004, the hygiene of foodstuffs

Regulation (EC) 2074/2005 